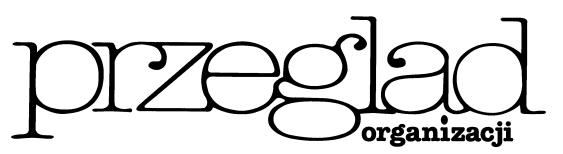

\title{
Utopia zarządzania
}

https://doi.org/10.33141/po.2005.11.01

Łukasz Sułkowski
Przegląd Organizacji, Nr 11 (790), 2005, ss. 7-9 www.przegladorganizacji.pl Towarzystwo Naukowe Organizacji i Kierownictwa (TNOiK)

\section{Wprowadzenie}

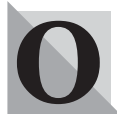
kreślenie „utopia” znalazło się w języku humanistyki w XVI w. za sprawą dzieła Tomasza Morusa. Jak pisze Jerzy Szacki, utopia to „... nieustająca podróż do kraju, którego nie ma, poszukiwanie wyspy szczęśliwej”1). Jest ona jednocześnie ideałem, mrzonką i projektem eksperymentu społecznego. Jednak istota myślenia utopijnego leży u podstaw funkcjonowania wszystkich wspólnot. Jest nieodłączna kondycji ludzkiej, dążącej do budowy idealnej społeczności wysublimowanej ponad ułomności rzeczywistych wspólnot ${ }^{2}$. Owa doskonała wspólnota odznaczać się będzie pełną stabilnością, trwałością, sprawiedliwością osiągając swoiste status quo - „końca historii”"3).

Co to ma wspólnego z zarządzaniem? Otóż można postawić tezę, że nauki o zarządzaniu budując swoją tożsamość również sięgnęły do myślenia utopijnego, proponując explicite lub implicite wizję „lepszego świata" i pełni poznania po wdrożeniu ideałów naukowego zarządzania. Celem tego artykułu jest próba rekonstrukcji owych utopii.

\section{Modernistyczne źródła utopii zarządzania}

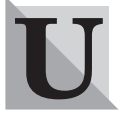

topia to wiara w osiaggnięcie stanu idealnego, doskonałego, ostatecznego i nieprzekraczalnego, w którym nie ma już nic do poprawienia ${ }^{4}$. Zarządzanie wyrasta $\mathrm{z}$ ducha myśli modernistycznej opartej na wierze w pełnię racjonalności i postępu. Stąd u podstaw głównego nurtu naukowego zarządzania tkwi nowoczesna utopia racjonalnej, sprawiedliwej i postępowej organizacji jako źródła trwałego ładu społecznego. Wdrożenie wyrafinowanych idei zarządzania jakością, strategią oraz kultura organizacyjną miałoby prowadzić do stanu trwałej i dynamicznej doskonałości. Na poziomie makro byłby to produktywny i stabilny wolny rynek wyposażony w mechanizmy selekcji lepszych rozwiązań. $\mathrm{Na}$ poziomie mikro stan idealny byłby źródłem satysfakcji nie tylko dla zarządzających, właścicieli, ale również klientów oraz pracowników i innych członków społeczeństwa (interesariuszy). Klamrą spinającą owo status quo na poziomie mezo jest efektywna organizacja oparta na racjonalnych i uniwersalnych zasadach naukowego zarządzania. Warunkiem osiągnięcia owej doskonałości jest planowanie i nadzór prowadzony przez światłych i odpowiedzialnych menedżerów, których skojarzyć można z utopijnymi władcami-mędrcami ${ }^{5)}$.

Różni autorzy wskazują na inne wątki myślenia utopijnego w zarządzaniu. G. Burrell i K. Dale zauważają, że u podstaw tworzenia ładu organizacyjnego leżą domyślne, uważane za oczywiste zasady: ochrony grupy organizacyjnej, wytyczania granic organizacji, racjonalnej i harmonijnej kontroli oraz formalizacji wzorów organizowania ${ }^{6)}$. P. Reedy uważa, że guru zarządzania często eksploatują motywy utopijne, odwołując się do wizji idealnej organizacji prowadzącej do doskonałego ładu społecznego ${ }^{7}$. Jako przykład opisywana jest koncepcja „organizacji uczącej się” Petera Senge'a stanowiąca podstawę „,społeczeństwa zorientowanego na wiedzę"8).

Chciałbym zaproponować nieco inną analizę utopijnych wątków w zarządzaniu odwołującą się do podziału na utopie społeczne i epistemologiczne. „Naukowe zarządzanie" już od swego zarania miało w sobie elementy utopii społecznej oraz utopii epistemologicznej. W sferze społecznej była to wiara w zbudowanie dzięki zarządzaniu społeczeństwa doskonałego, racjonalnego i szczęśliwego. W znaczeniu epistemologicznym było to neopozytywistyczne dążenie do odkrycia pełni prawdy i osiągnięcia pewności poznania organizacji i zarządzania.

\section{Utopia społeczna}

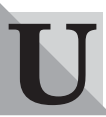

topia społeczna zarządzania opiera się na wierze w stworzenie lepszego ładu społecznego dzięki wdrożeniu w życie idei naukowego zarządzania. Wielu teoretyków i praktyków zarządzania to wizjonerzy. Twórcy naukowego zarządzania, jak chociażby Frederic Winslow Taylor czy Henry Fayol wierzyli, że tworzona przez nich nauka jest potrzebna ludzkości. Przekonanie to jest nieobce współczesnym guru zarządzania, takim jak: Peter Drucker, Tom Peters, Robert Waterman i Charles Handy ${ }^{9}$. Utopia społeczna zasadzała się na wierze, że dzięki zarządzaniu praca człowieka miała przynosić najlepsze możliwe efekty, które miały być sprawiedliwie dzielone pomiędzy pracodawców i pracobiorców. Organizacja jest najważniejszym miejscem samorealizacji człowieka - zarówno jako pracownika, jak i konsumenta. Cechuje ją koncentracja na ideologicznej wizji ładu społecznego opartego na światłych zarządzających, kierownikach racjonalnych pracowników. Menedżerowie, w myśl utopijnej interpretacji, nie są 
egoistami dążącymi do dominacji nad innymi ludźmi i zabezpieczenia uprzywilejowanej pozycji, lecz dobroczyńcami ludzkości budującymi nowy, lepszy porządek społeczny. Zatem naukowe zarządzanie to dyscyplina, która od początku swojego istnienia tworzyła wyrazistą, choć utopijną misję mającą prowadzić do emancypacji ludzkości.

Poszukując zrębów społecznej utopii zarządzania chciałbym wskazać na kilka wątków, które przewijają się w zarządzaniu, tworząc jego swoistą mitologię.

- Organizacja powinna stanowić najważniejsze źródło tożsamości i samorealizacji jednostki.

- Praca i konsumpcja stanowią podstawowe wymiary egzystencji ludzkiej.

- Menedżeryzm jest najdoskonalszym systemem władzy społecznej, a menedżer to bohater naszych czasów.

- Dążenie do sukcesu zawodowego stanowi podstawę kodeksu etycznego współczesności.

- Podstawą dobrobytu i ładu społecznego we wspólnotach ludzkich może być wyłącznie wolny rynek.

- Pieniądz jest uniwersalną miarą wartości.

- Własność stanowi sprawiedliwą i jedyną racjonalną bazę dla stratyfikacji społecznej.

- Wiedza powinna być instrumentem panowania nad rzeczywistością.

Powyższy wykaz jest jedynie propozycją powiązanych ze sobą norm, jednak wydaje się, że tworzy spójny obraz utopijnego „menedżerskiego społeczeństwa”. Taki wyidealizowany obraz ładu społecznego znaleźć można w najbardziej rozpowszechnionych i zakorzenionych w zarządzaniu metaforach organizacji (maszyna, organizm, uczenie się, funkcjonalna kultura $)^{10)}$.

\section{Utopia epistemologiczna}

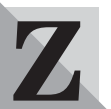
arządzanie tworzone było w duchu nauki pozytywnej, czerpiącej z przyrodoznawstwa i nauk inżynieryjnych. Można wymienić kilka utopijnych neopozytywistycznych postulatów przyjętych przez naukowe zarządzanie.

- Wiara w ciągłość postępu naukowego i kumulatywny rozwój wiedzy.

- Poszukiwanie uniwersalnej, niezawodnej i pewnej metody naukowej11)

- Matematyzacja i formalizacja pozwalająca opisać procesy zarządzania w postaci wzorów, funkcji i modeli matematycznych ${ }^{12)}$.

- Redukcjonizm pozwalający na identyfikację wpływu przyczynowego wszystkich zmiennych działajacych w procesach zarządzania.

- Dążenie do stworzenia skończonego, deterministycznego wyjaśniania przyczynowego procesów zarządzania.

Utopia epistemologiczna wskazująca na możliwość stworzenia deterministycznego, zamkniętego systemu uniwersalnej i pewnej wiedzy w naukach o zarządzaniu okazała się mitem, który jednak pokutuje w naszej dyscyplinie. Neopozytywistyczny obraz zarządzania, mimo że poddany został surowej krytyce, nadal głęboko tkwi w umysłach wielu badaczy i specjalistów od zarządzania. Często pozostaje on rodzajem niezbyt świadomej, „zdroworozsądkowej” wizji uprawianej dyscypliny, która nie wymaga stawiania kłopotliwych pytań o podstawy poznawcze ${ }^{13)}$.

Wydaje się jednak, że rozwój nauk o zarządzaniu i krytyczna recepcja przedstawionych postulatów zbliżają nauki o zarządzaniu do innych nauk społecznych, obnażając utopijność postulatów epistemologicznych przyjmowanych przez ojców-założycieli naukowego zarządzania. Współczesne zarządzanie w coraz większym stopniu staje się nauką interdyscyplinarną, autorefleksyjną oraz hermeneutyczną. Nauki o zarządzaniu ograniczają orientację scjentystyczną nakładającą na dyscyplinę społeczną sztywny gorset metodologiczny, którego ideał stanowią nauki przyrodnicze. Proces poznania w zarządzaniu nie opiera się na odzwierciedlaniu obiektywnie istniejącej rzeczywistości, ale jej współtworzeniu w intersubiektywnych procesach negocjacji znaczeń ${ }^{14)}$. „Refleksyjność” poznania, charakterystyczna dla nauk społecznych, oznacza, że ludzie tworzący i uzgadniający znaczenia odznaczaja się samoświadomością i interpretując wiedzę o świecie zmieniają własne zachowania. Wiedza nauk o zarządzaniu ma charakter nieuniwersalny, przybliżony i niepewny. Nauki te ulegają znacznym wpływom kontekstu społecznego i kulturowego, który przejawia się kognitywną rolą języka, nieredukowalnym oddziaływaniem wartości na poznanie oraz historycznymi kryteriami racjonalności naukowej (relatywizm kulturowy). Nauki o zarządzaniu są uwikłane w praktykę, co oznacza, że współtworzą badaną rzeczywistość. Pierwotne w rozumieniu organizacji i zarządzania są kategorie potoczne i intuicyjne. Nauki o zarządzaniu tworzą i podtrzymują „organizacyjny światopogląd”, który wiąże racjonalizację i dążenie do efektywności z wzmocnieniem władzy ekspertów oraz technokratów ${ }^{15)}$. Zarządzanie, podobnie jak inne nauki społeczne, znajduje się w kole hermeneutycznym ${ }^{16)}$. Sposoby interpretacji rzeczywistości uzależnione są od kulturowo nabytego aparatu kognitywnego i językowego, który to z kolei zmienia się pod wpływem tych interpretacji. Prowadzi to do świadomości wpływu kontekstu kulturowego na koncepcje zarządzania, co prowadzi do relatywizmu kulturowego. Nauki o zarządzaniu mogą łączyć różne względy badawcze. Podejście techniczne zaczerpnięte $\mathrm{z}$ nauk inżynierskich i ekonomicznych pozwala dokonywać manipulacji przedmiotami i technologiami prowadzącymi do wzrostu efektywności działalności człowieka. Podejście pragmatyczne koncentruje się na poprawianiu komunikacji, tworzeniu kultury i struktur władzy pozwalających na doskonalenie możliwości współdziałania ludzi. Nurt refleksyjny umożliwia analizę krytyczną skutków rozwoju podejścia technicznego i pragmatycznego ${ }^{17)}$. Nauki o zarządzaniu na obecnym etapie rozwoju powinny wyzbyć się uniwersalistycznych ambicji. Rozumiane jako dyskurs lokalny niosa aspekty twórcze, podczas gdy wielkie działania, systemy, teorie są, jak dotąd, nieskuteczne poznawczo. Konieczne jest również zwrócenie uwagi na historyczność i relatywizm kulturowy tworzonych koncepcji. Przyjmowa- 
nie zróżnicowanych perspektyw epistemologicznych przyczynia się do wzbogacenia nauk społecznych. $\mathrm{Na}$ obecnym etapie rozwoju nauk o zarządzaniu najbardziej owocnym stanowiskiem epistemologicznym wydaje się być eklektyzm, który dopuszcza łączenie różnych, nawet niespójnych podejść poznawczych i epistemologicznych ${ }^{18)}$.

W świetle wskazanych trendów rozwoju nauk o zarządzaniu „twarde”, neopozytywistyczne podejście naukowego zarządzania można uznać za rodzaj utopii poznawczej. Współczesne nauki o zarządzaniu są zorientowane społecznie i daleko im do ideałów scjentyzmu.

\section{Postmodernistyczny upadek utopii zarządzania}

$\mathbf{N}$ eopozytywistyczny, taylorowski projekt „naukowego zarządzania" nie ziścił się. Nie w tym znaczeniu, że nauka i praktyka zarządzania nie uzyskały znaczenia. Wręcz przeciwnie, jest to współcześnie niesłychanie wpływowa dziedzina akademicka o potężnym oddziaływaniu społecznym. Chodzi raczej o zupełnie inny obraz „naukowości” zarządzania, które nie ma szans ani na zbawienie ludzkości przez poznanie, ani nie może zaoferować ścisłej wiedzy, o jakiej marzyli ojcowie założyciele „naukowego zarządzania”. Współcześnie jesteśmy świadkami chylenia się ku upadkowi modernistycznej utopii zarządzania. Następuje schyłek utopii epistemologicznej i społecznej zarządzania. Nie ma nadziei, że przedstawiona zostanie prawda ostateczna o zarządzaniu objawiona przez guru, czy mozolnie odkryta w badaniach empirycznych. Menedżerowie nie są skazani na pełnię racjonalności, poznania i postępu; „w przeciwieństwie do swych przodków z okresu narodowego budownictwa, globalne elity nie mają żadnej misji do spełnienia; nie czują potrzeby i nie mają zamiaru nikogo nawracać, nieść kaganka oświaty, nauczać, pouczać ani zmieniać"19). Organizacje mają być konkurencyjne, przynosić zyski właścicielom i nie mają szansy na osiągnięcie doskonałości.

\section{Wnioski}

M ożna przekornie stwierdzić, że utopia jest potrzebna zarówno jednostkom, jak i wspólnotom. Ludzie i społeczności mają potrzebę działania celowego i sensownego, które dąży do osiągnięcia stanu idealnego. Utopie są źródłem tego sen$\mathrm{su}^{20)}$. Dlatego wiara w misję, jaką mogą pełnić nauki o zarządzaniu, jest źródłem identyfikacji i tożsamości dla praktyków i teoretyków zarządzania. Jednak bezkrytyczne przywiązanie do utopii społecznej lub epistemologicznej zarządzania sięgającej swoimi korzeniami tayloryzmu niesie ryzyko dogmatyzmu. Teoretycy i praktycy zarządzania są współcześnie odzierani ze złudzeń, że własna dyscyplina ma wielką misję poznawczą i emancypacyjną. Zdanie sobie sprawy ze znaczenia myślenia utopijnego $\mathrm{w}$ zarządzaniu to lekcja pokory skłaniająca do refleksji nad rozwojem tej nauki. Wyłaniający się obraz problematyki zarządzania sugeruje myślenie o zbliżeniu pola zainteresowań do nauk społecznych i humanistycznych oraz podjęciu zadania krytycznej autoanalizy istniejących koncepcji. Trudno również uwolnić się od wrażenia, że utopijne myślenie ujawnia się w tworzeniu i recepcji idei guru zarządzania. Okruchy utopijnych i mesjanistycznych motywów w naukach o zarządzaniu znaleźć można w modach i pseudouniwersalnych receptach. Wydaje się, że uświadomienie sobie utopijności takiego podejścia będzie skłaniało do bardziej sceptycznego traktowania nowych koncepcji zarządzania.

dr hab. Łukasz Sutkowski

profesor Społecznej Wyższej Szkoły

Przedsiębiorczości i Zarządzania w Łodzi

\section{PRZYPISY}

1) J. SZACKI, Spotkania z Utopia, Iskry, Warszawa 1980, s. 13.

2) Z. BAUMAN, K. TESTER, O pożytkach z wątpliwości. Rozmowy z Zygmuntem Baumanem, Sic, Warszawa 2003, s. 66 .

3) F. FUKUYAMA, The End of History and the Last Man, Free Press, New York 1992.

4) L. KOŁAKOWSKI, Moje stuszne poglady na wszystko, Wydawnictwo Znak, Kraków 1999, s. 11-12.

5) Porównaj: Z. BAUMAN, Utopia bez toposu, [w:] Kultura $w$ czasach globalizacji, IFiS PAN, Warszawa 2004, s. 22.

6) G. BURRELL, K. DALE, Utopiary: Utopias, Gardens and Organization, [w:] Utopia and Organization, red. M. PARKER, Blackwell, Oxford 2002, s. 106-109.

7) P. REEDY, Keeping the BlackFlag Flying: Anarchy, Utopia and the Politics of Nostalgia, [w:] Utopia and Organization, red. M. PARKER, Blackwell, Oxford 2002, s. $175-176$.

8) P. SENGE, The Fifth Discipline: the Art and Practice of Learning Organization, Century Business, London 1993.

9) A. PINNINGTON, Charles Handy: The Exemplary Guru, „Philosophy of Management. Formerly Reason in Practice", vol. 1, nr 3, 2001.

10) G. MORGAN, Obrazy organizacji, PWN, Warszawa 1997.

11) Więcej na ten temat: Ł. SUŁKOWSKI, Neopozytywistyczna mitologia $w$ nauce o zarzadzaniu, „Organizacja i Kierowanie", nr 1 (115), 2004, s. 3-14.

12) Porównaj: H. Le CHATELIER, Filozofia systemu Taylora, [w:] Twórcy naukowych podstaw organizacji, red. J. KURNAL, Warszawa 1972, s. 104.

13) Więcej na ten temat: Ł. SUŁKOWSKI, Epistemologia w naukach o zarzqdzaniu, PWE, Warszawa 2005.

14) N. ROMM, Responsible Knowing: A Better Basis for Management Science, „Philosophy of Management. Formerly Reason in Practice", vol. 2, nr 1, 2002.

15) W.R. SCOTT, Organisations. Rational, Natural and Open Systems, Englewood Cliffs 1987, s. 5.

16) H.-G.GADAMER, Truth and Method, Seabury Park, New York 1975.

17) Porównaj: J. HABERMAS, Teoria dziatania komunikacyjnego, PWN Warszawa 1999.

18) Więcej na ten temat: Ł. SUŁKOWSKI, Epistemologia w naukach o zarzadzaniu, PWE, Warszawa 2005.

19) Z. BAUMAN, Utopia bez toposu, [w:] Kultura w czasach globalizacji, IFiS PAN, Warszawa 2004, s. 27.

20) H. CYRZAN, O potrzebie utopii, Wydawnictwo Adam Marszałek, Uniwersytet Gdański, Toruń 2004, s. 9. 